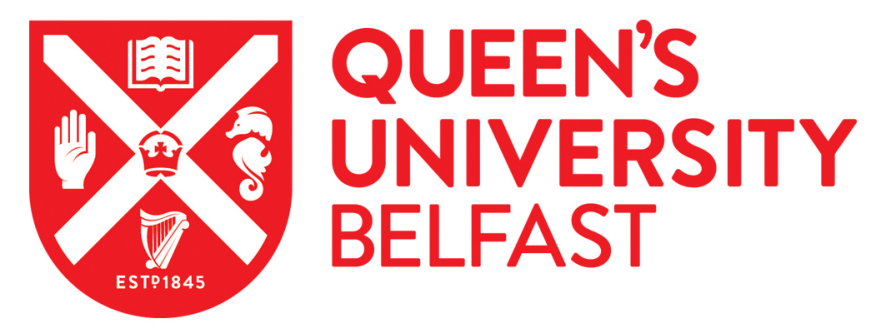

\title{
Costing in the early Industrial Revolution: gradual change to cost calculations at US cloth mills in the 1820 s
}

Gervais, P., \& Quinn, M. (2016). Costing in the early Industrial Revolution: gradual change to cost calculations at US cloth mills in the 1820s. Accounting History Review, 26(3), 191-217.

https://doi.org/10.1080/21552851.2016.1229265

Published in:

Accounting History Review

Document Version:

Peer reviewed version

Queen's University Belfast - Research Portal:

Link to publication record in Queen's University Belfast Research Portal

Publisher rights

Copyright 2018 Taylor and Francis. This work is made available online in accordance with the publisher's policies. Please refer to any applicable terms of use of the publisher.

\section{General rights}

Copyright for the publications made accessible via the Queen's University Belfast Research Portal is retained by the author(s) and / or other copyright owners and it is a condition of accessing these publications that users recognise and abide by the legal requirements associated with these rights.

Take down policy

The Research Portal is Queen's institutional repository that provides access to Queen's research output. Every effort has been made to ensure that content in the Research Portal does not infringe any person's rights, or applicable UK laws. If you discover content in the Research Portal that you believe breaches copyright or violates any law, please contact openaccess@qub.ac.uk. 
Costing in the early Industrial Revolution: gradual change to cost calculations at US cloth mills in the 1820s 


\begin{abstract}
This paper details the cost accounting practices at some US cotton mills in the early $1800 \mathrm{~s}$. While some extant literature suggests these practices were more akin to management accounting, this paper takes a different view. Drawing on an institutional lens and some reverse engineering of cost calculations, we suggest that the calculations at these mills were indeed institutionalized and a merchant mindset on costs and profits was engrained within them. In this regard, the cost calculations were based on the comparative quality of cloth, and not costs traced specifically to a particular product. However, changes began to emerges toward the end of the $1820 \mathrm{~s}$, when the cost calculations were in some instances more specific to the particular product. This gradual change may be due to external market and economic forces effecting existing practices.
\end{abstract}




\section{Introduction}

A large body of research has traced the beginnings of cost accounting back to at least the eighteenth century or earlier. In light of the many elements of cost accounting used by British estate owners, coal mine operators, and others, it has been questioned whether "a relevant distinction between 'pre-modern' and 'modern' business accounting" existed at all (Oldroyd 1999, 197; Fleischman and Parker 1997; Scorgie 1999). Far from transitioning at some point after the mid-nineteenth century, as was once thought, modern cost accounting likely followed a continuous developmental path, a view in keeping with the current reluctance to see the Industrial Revolution as a clear, catastrophic break (Berg 1994; Mokyr 2005). Studies on the rhythm of this development, and on the multiple factors which promoted or hindered it in each country are needed, as the basic principles of cost management were observable long before the development of the modern, industrial factory and the associated multidivisional corporation (Edwards et al. 2009).

The present paper focuses on the development of cost accounting by focusing specifically on the issue of cost calculations in the 1820 s at the first large, integrated and wholly mechanized cotton textile mills in the United States (US), set up in Waltham and Lowell, Massachusetts. Drawing on an institutional framework on change and stability in management accounting practices by Burns and Scapens (2000), we re-examine some prior work by Tyson (1992, 1998). In doing so, we aim to establish the cost accounting practices at the textile mills as institutionalized and follow their path of stability and/or change to determine how and why they evolved (or not). To do this, we explore the origins of these same practices by working backwards mathematically on cost sheets, determining not only the source of the numbers, but also whether they may have been of use for managerial decisions as extant work suggests. The remainder of this paper is structured as follows. The next section provides some background and context on the Boston Manufacturing Co. (BMC)'s Waltham Mills, including some mention of their costing practices. This is followed by a description of our theoretical lens, the work of Burns and Scapens (2000) as mentioned. We then detail the BMC the memoranda, covering cost allocating at the mills as a function of cloth quality and then how costs were used for managerial purposes move. Then, we detail a move towards the use of tracing actual costs to products, particularly at the Merrimack Mill in the city of Lowell and what may have been the forces behind the change. Throughout these sections we will discuss how the cost accounting practices changed/remain stable over time drawing on Burns and Scapens (2000). The final section offers some concluding thoughts. 


\section{The Waltham and Merrimack Mills - context and costing}

This section draws on several sources to recount the story of the Waltham and Merrimack Mills, almost all of them already used in Tyson's prior accounts $(1992,1998)$. Writings by Appleton 1848, 1858; Gibb 1950, Gregory 1975, Mailloux 1957 and Ware 1931 formed an initial base, with detailed presentations also provided by Dalzell 1987, Dublin 1979, Jeremy 1981, Lubar 1983, McGouldrick 1968 and more recently Meyer 2003 and Rothenberg 2000.

The first mechanized spinning and power-loom weaving factory in the US was built in Waltham, Massachusetts by the BMC, a Massachusetts corporation formed in 1813. There were twelve stockholders, the "Boston Associates", as they were later called. Three of them, Patrick Tracy Jackson, Francis Cabot Lowell and Nathan Appleton (all wealthy Bostonian merchants) were active managers at BMC. The factory combined for the first time mechanized spinning and power-loom weaving, and was quite profitable. Lowell had smuggled sketches of a power-loom from England, and managed to build the first fully operational US power-loom with the help of Paul Moody, a gifted mechanic. The first cloth was produced in 1816 . By 1820 , BMC had increased its capital from $\$ 400,000$ to $\$ 600,000$, with a total of 23 stockholders. Production expanded at Waltham, but was limited in terms of water-based power. At this time, two new mills had been added and a bleaching plant.

The original Waltham mill produced coarse, cheap plain cloth at first, but diversified production, with bleached and finer cloth grades being produced in the two new mills from 1819 onwards. By 1822, Appleton and Jackson, who had managed BMC since Lowell's death in 1817 , decided to produce calico-type printed cloth. As they were already using all water power available at Waltham, they formed a second Massachusetts corporation, the Merrimack Manufacturing Company (MMC), with the stockholders mostly drawn from the same circle of associates who funded BMC. Seven new stockholders were added, most notably the Boott brothers, who would play a key managing role thereafter, and a British correspondent, Timothy Wiggin, who gave the associates continued access to British technical innovation. MMC used the water power of the Merrimack river falls at East Chelmsford. The rights to the water power belonged to a local corporation, the Proprietors of the Locks and Canal on the Merrimack River, which Appleton and Jackson had previously acquired. The venture into printed cloth, which started operations in 1823, proved as successful as the earlier production of plain cloth. The success was so great that in the next 5 years a slightly enlarged group of 
investors formed three more corporations; the Hamilton Manufacturing Company (HMC) (1825), the Appleton Manufacturing Company (AMC) (1828) and the Lowell Manufacturing Company (LMC) (1828). Each owned several mills along the Merrimack falls and a large industrial town which grew around these mills was incorporated as a separate township in 1826 under the name of Lowell, in honor of the deceased Francis Lowell. While the five corporations, BMC and the four at Lowell were legally distinct, they had interlocking boards and stockholders and were closely controlled by Appleton, Jackson, the Boott brothers and Moody. Indeed, these corporations and their mills operated more as specialized divisions of a large firm than as independent entities. Additionally, the entire output of all the mills went to one marketing agent, Nathan Appleton, himself, who sold it through his own commission house.

Technically very advanced, these ventures benefited from the start from detailed accounting procedures. Jackson and Appleton collected data from the "agents" - operational managers who oversaw the various mills. Their private papers, held at the Massachusetts Historical Society contain a series of cost memoranda drawn up between 1824 and 1829 . These provide abundant costing information, particularly unit costs for each textile woven by the various mill units. It has long been known by accounting historians that from the outset the records kept by Jackson, the agent and bookkeeper at Waltham, were detailed and ahead of their time in many respects (Gibb 1950, 51; Lubar 1983, 159; Previts and Merino 1998, 58). David M. Porter has identified what he called "a conscientious effort [...] to accumulate costs throughout the production process" dating to $1817(1980,6)$. The results of this effort, according to Porter, amounted to "the rudiments of a costing system", but what was lacking at that time was the calculation of unit costs per grade of cloth. In the 1990s, Thomas Tyson brought to light several memoranda written by Nathan Appleton between 1826 and 1828 , listing detailed unit costs at the MMC and other Lowell corporations. According to him, these memoranda showed that "a variety of detailed cost per unit calculations were conducted" in the mills at Lowell by the end of the 1820s (Tyson 1992, 12). More broadly, they represent signs of "management accounting", a form of cost accounting suitable for "making decisions, solving problems [and] controlling operations", although not encompassing labor discipline (Tyson 1998, 213, 216). For Tyson, who was answering to earlier doubts raised by Hoskin and Macve (1996), numerous instances of and references to unit cost data indicate "that cost data were used managerially for both decision making and management control [...] make-or- 
buy, subcontracting, keep-or-replace, product-choice, plant-expansion and product-pricing decisions were informed by cost data" (Tyson 1998, 222-224). Indeed, since all corporations formed in Waltham and Lowell produced for stock rather than to order, product choice was an obvious topic on which costing would lead to managerial control.

A central argument of this paper is that there may be a different meaning to early costing efforts at Waltham, one more closely related to an earlier sphere of accounting developed in the 18th-century merchant world. While Tyson (1998) rightly notes the widespread use of cost accounting for managerial purposes at various mills in Lowell in the 1830s, evidence of similar use in the 1820 s is sparser, and largely limited to the printing process. We propose this sparser use stems from the design and specifics of the costing processes originally created at Waltham for BMC, which in turn can be explained by their belonging to what Tyson himself called a "transitional form of accounting", falling between 18th-century mercantile accounting and 20th-century industrial accounting (Tyson 1998, 213, 224). These early 1820s unit costs, as we will show, were based on the allocation of factory-wide aggregate data. This data was themselves derived from the characteristics of various types of cloth. Thus, costs were reflective of hierarchies of cloth quality, themselves linked to hierarchies of price, a key issue for merchants in the Early Modern era (Gervais 2012; Grenier 1996; Margairaz 2014; McWatters and Lemarchand 2013; Stanziani 2003). Our contention is that to the end of the $1820 \mathrm{~s}$, this kind of costing was used to check the adequacy of sales prices and product quality. The costs may also may have been used to manage production costs, but this was not the primary objective of the managers who drew them up. These managers were merchants, and if the way they constructed their calculation is any guide, they wanted above all to be able to link quality assessments, overall costs, and sales prices. The time-honored pricing process among merchant circles had always called for an intuitive, rule-of-thumb approximation, often barely explicitly expressed - choosing the proper markup was an art, not a science. However, as BMC in Waltham benefited from a quasi-modern cost accounting system, its managers could develop a very elaborate, formalized and quantified process which would help them control sales prices according to what they saw as the proper mix of products they should offer. By the same token, this particular type of cost calculation gives us a unique window into the way merchants linked production costs to sales price in the pre-industrial world. 


\section{Theoretical lens and method}

As noted earlier, for a theoretical underpinning to this study we draw on the work of Burns and Scapens (2000). Prior literature has similarly done so - see for example as Spraakmann (2006), Quinn (2014), Quinn and Jackson (2014) and Hiebl, Quinn, and Martinez-Franco (2015). Burn and Scapens (2000) outline, from a management accounting perspective, how rules (how things should be done) and routines (how things are done) interact over time to become taken-for-granted (institutionalized) practices. Such practices are often resistant to change and engrained within an organization. Burns and Scapens (2000) treat rules and routines as a bundle, but later work by Quinn (2011) and Oliveira and Quinn (2015) suggests they are separable. Quinn (2011) for example suggests rules are formal, written and need not exist, while Oliveira and Quinn (2015) argue rules need not be written and are formal cognitive structures. In the context of this study, rules by this definition may be more applicable, as we attempt to compile cost calculation methods (see below). Routines in the archival records can be found in cost calculation outputs/reports, which are artefacts of the underlying routines. By establishing the cost accounting practices at the various cloth mills as routinized- and possible based on a rule (i.e. a formula or method), we can determine them as institutionalized (or not) and endeavor to determine if the changed/remained stable over time. Pentland (2011) provides a more refined definition of routines than Burns and Scapens (2000). Pentland (2011) notes four essential criteria of routines. These are: 1) routines are repetitive, 2) a recognizable pattern of action occurs on each performance, 3) actions are interdependent, and 4) multiple actors are involved. Typically, bookkeeping and cost accounting practices meet these four criteria. By applying these four criteria to the cost accounting practices of the mils, we can establish them as as least routinized and potentially institutionalized practices per Burns and Scapens' (2000). We can also examine how existing institutions influenced these practices, and explore for internal and/or external influences driving change/promoting stability.

As regards our methods, we draw primarily the private papers of Appleton and Jackson held at the Massachusetts Historical Society, as well as on the BMC account books, kept at the Baker library of the Harvard Business School. The period on which we focus spans the 1820s. The earliest used material, yearly inventories found in the BMC books, dates back to 1819 , but we focus most on unit cost calculations at Waltham and Lowell dating from 1820s to the beginning of the 1830s. They are known primarily through a series of sheets on which the 
calculations were made. These sheets were not part of the normal accounting flow, and were drawn up separately. Those sheets which have survived were mostly those written by Nathan Appleton and Patrick Jackson, the two key business managers noted earlier. They were kept in their personal papers, with Appleton's calculation mostly on scrap of papers within his correspondence, and found almost every year from 1825 to 1830. In addition, for the years 1828-1829, Jackson recorded in a separate notebook most of his known "memoranda", as they both called these calculations. In most cases, these costing efforts took place in conjunction with one of the biannual settlement of the accounts of each company, the date of the settlement being different from one corporation to the next (end of February and end of August for BMC, for instance, as opposed to end of April and end of October for MMC).

Several authors, most notably Lubar (1983, 151) Porter (1980) and above all Tyson (1992, $11-14 ; 1998,216)$, who was the first to precisely describe and study them, refer to these memoranda from the 1820s. Several of the 1827, 1828 and 1830 memoranda in Appleton's papers in particular have been discussed by Tyson $(1992,11)$ as signs of cost control, though he seemed to conclude later on, speaking of a similar memorandum, that "the available evidence does not permit a more precise conclusion about the actual use of cost information" which can be found within these sources (Tyson 1998, 218). Indeed, Porter (1980) for his part only referenced reports from LMC in the 1830s, and in his answer to Hoskin and Macve (1996), Tyson (1998) also mostly used material from the same later period. This is where we propose to go a step further, examining how several of these earlier sheets from the $1820 \mathrm{~s}$ were constructed. Our approach is to attempt to retrace the mental and mathematical processes through which the numbers of the memoranda were arrived at, and to derive as much information as possible from these processes on the assumptions and focus of the people who used them. In essence we are reverse engineering the cost calculations. Doing this, we hope, will not only provide more detail on the cost calculation process, but also provide insights into how the cost calculations may have become institutionalized and thus trace change over time

\section{Costs calculations as a function of quality - the BMC memoranda}

As noted above, we attempt to retrace the costs calculations of the various mills in which Jackson and Appleton were involved in the 1820s. Both their efforts included unit costs calculated to one-hundredth of a cent, and allocated direct costs (cotton, labor or spinning, 
weaving) and indirect costs (overhead or repairs) to each cloth type. We analyzed the figures given by both men in several of their earliest memoranda, and concluded that the figures were not based on actual cost or standard cost - at least in the contemporary meaning of the latter. Instead, they were generated by taking factory-wide inputs and outputs, and allocating these values over several different types of cloth according to their level of quality.

The costing method can be observed most clearly in the earliest memorandum by Jackson, dated August 30th, 1828. This presents unit costs and profit for all the cloth produced by BMC at Waltham. A copy of the same memorandum is also found in near identical form in the Appleton papers, and we provide an exact transcription in Table $1^{1}$. On the upper half of the memorandum, Jackson recorded the quantity (in yards) and weight (in pounds) produced in the year for each cloth grade, as well as the total cost of cotton, labor, and general expenses/repairs for each grade. The cloth grades were listed in two groups, according to where they were produced. The top group (BMC1 to S9) were produced in the two older mills in Waltham, which from an accounting point of view made up a single mill unit. The bottom group (H7 and P8) referred to a newer single-factory mill unit built later. On the lower part of the memorandum, the input costs are calculated per 1000 yards and per pound. The market price per 1000 yards is also shown and a profit per 1000 yards deduced from the two figures. The last column repeats the total cost per cloth grade as listed "above" in the upper part of the table.

[insert Table 1 about here]

The cost sheet per Table 1 certainly appears to be a careful calculation of costs and profits, likely based on actual cost as traced to each cloth. However, if it used actual costs, two columns do not seem to fit. First, for each cloth grade, Jackson specified a "beers" number. A "beer" (also bier) is a set number of warp threads, around 40 in the Imperial system. The beers number is typically the total number of warp threads in one foot of cloth. Thus a 40 beers cloth would have 1,600 such threads per foot of cloth and so on. Higher beer counts imply a thinner thread, with a resulting finer and lighter cloth. In other words, the beers number was a proxy for cloth quality. Second, a column shows the "profit on scale of 31/07 for BMC". Trying to make sense of these two columns, we realized that for each cloth, Jackson gives a profit figure by assuming that profit should be "in proportion" (an expression often used in other memoranda) to its beers number compared to that of the BMC1 cloth. The 
BMC1 cloth grade was chosen as a yardstick, it seems, as it was chronologically the first cloth produced in Waltham (its beers count was neither highest nor lowest). Working backwards to verify this, using cloth $\mathrm{W}$ as an example, it had 66 beers to the 40 beers of BMC1 - a proportion of $165 \%$. The profit for cloth BMC1 was calculated at $\$ 31.07$ per 1000 yards, therefore the profit on cloth W should be $165 \%$ of $\$ 31.07$, or $\$ 51.27$. We checked each cloth and the answer was correct using this method. Thus, we can represent what Jackson did by the following formula (Figure 1):

[insert Figure 1 here]

This use of beers numbers was intriguing, and we checked if input costs could be in proportion to them also. This led us to a second discovery in that a more complex beers-based formula had been used to allocate both overhead and labor across all cloth types in the upper part of the memorandum as per Table 1. The formula was as follows (Figure 2):

[insert Figure 2 here]

To put the above formula in words, for each of the two mill units which made up the BMC in accounting terms, the percentage of labor or overhead allocated to a given cloth was a percentage of total labor/overhead cost for the mill, equal to the proportion for that cloth of total yards weighed by beers number. When we derived the formula, the fact that the percentage for each cost (wages and overhead) was equal removed any doubt that this was but the result of a mathematical computation, and was not of a process of recording of actual costs. To give an example, the BMC 1 cloth incurred $18.397 \%$ of the total wage cost the accounting books listed as spent in "factories $1+2$ " (which made up the first accounting unit), and $18.397 \%$ of total overhead cost for the same two factories; and the number of yards of BMC1 times its beers number $(310,671$ x 40 - see Table 1$)$ represented $18.397 \%$ of the total yards times beers for all cloth types $(310,671 \times 40+311,351 \times 32+\ldots$ etc. $)$. The three percentages were identical to seven decimal places (not shown here), which suggest coincidence in our interpretation quite unlikely. This rather complex calculation (per Figure 2) shows that Jackson considered that higher beers count cloth was more expensive to make. However, he did not consider it necessary to develop tools to determine labor costs per cloth type. His accounting records could be used to determine how much had been paid for cotton, labor, etc. in total, and he also had a record of the number of yards of each cloth type woven 
annually in a given mill unit. However, no labor figure per cloth type could be drawn from these records, and the fact that he relied on a beers-based allocation suggest that data on labor cost could not come from a time-book recording labor activity. Indeed, there is no sign anywhere in the archival records of any process recording the labor or maintenance hours expended on each type of cloth. Thus, an improvised solution was developed by Jackson cloth quality would serve as a substitute for actual observation, with higher-count cloth assumed to cost more in terms of labor or overhead.

What about the cost of cotton? The cotton weight was not the overall amount used according to the books, but a smaller amount. The BMC account books recorded $629,189 \mathrm{lbs}$ of cotton used in 1828, while in the memorandum the total is $560,000 \mathrm{lbs}$ (see Table 1). ${ }^{2}$ This implied an $11 \%$ overall loss, a figure consistent with the actual rates of waste which, as we shall see later on, could be calculated for the mills of the MMC (see Table 6). If waste was factored into the weight recorded, it would indicate that cotton was weighed after weaving it - in other words, this was cloth weight, not cotton weight. Indeed, the memoranda (Table 1) also includes the yards contained in a pound of each cloth ("C 2.98 " means that one pound of the cloth BMC1 contained 2.98 yards of cloth). These figures correspond exactly to the number of yards produced divided by the number of pounds (again, for BMC1, 310,671 yards divided by 104,093 pounds equals 2.98 yards per pound). This provides quite conclusively evidence that the weight given is the weight of finished cloth (in "yards per pound"), not of cotton used including waste.

Another mathematical finding in the memoranda per Table 1, is that cotton price per pound is identical for all types of cloth (to six decimal places) throughout BMC - even though it was made up of three different buildings producing seven different types of cloth. The cost of cotton divided by total weight for each type of cloth equals 0.1429846 cents per pound in each and every case. This strongly suggests that there was no record of how cotton was used for each cloth within each factory, or even each mill unit. As various cotton qualities bought at various prices were used for various grades of cloth, the cost per pound of cotton used for each grade should have varied more than it did here. At best, it would seem cloth weight figures were obtained at the end of the production process - when it was baled in the counting room - by weighing the cloth produced. However, we should note the round figure of 560,000 lbs recorded as the total weight of cloth produced in 1828 - hardly a result one would expect if the cloth had been accurately weighed. On the other hand, yards per pound is not a linear 
function of the beers number, so that cotton weight could not simply be allocated according to a beers-based formula in the way labor was. Whatever the case, the point here is that cotton cost was also allocated a priori according to cloth weight, a proxy for cloth quality, without any attempt to measure ex post the actual cotton used in the production process. Higher-grade, finer cloth tended to be lighter, so that any approach based on final weight would lead to the assumption that finer cloth would use less cotton - even though producing finer cloth tended to generate more wastage, a point we will return to later.

Jackson's 1828 calculations were not a fluke. The earliest cost calculation sheets known for Waltham are two memoranda by Appleton, dating back to 1824. Appleton was second to Jackson in his management role at Waltham, and was a key figure in Lowell. These memoranda were titled "Proportions of Waltham cotton" and "Mem(o) of cost, sales, + profit on 1000 yds of Cloth - estimated on 12 months work from 31(st) Aug(t) 1822 to 30(th) Augt. 1823," (see Table 2). ${ }^{3}$ In both memoranda, the cost and profit on each cloth was compared to the cost and profit of the $\mathrm{BMC1}$, again according to the beers-based formulae in the 1828 memorandum (see Figure 1). Also, the beers-based profit was presented as the norm, the standard against which all other profits should be measured. In both memoranda, BMC1 cloth had a beer count of 40 , while the "N" cloth had a beer count of 32 . Since a beer count of 32 was $80 \%$ of a beer count of 40 , therefore $\mathrm{N}$ cloth "should" sell at a price which would bring in a profit equal to $80 \%$ of that of the BMC1 cloth. If the profit on 1000 yards of BMC1was $\$ 67.55$, then the profit on 1000 yards of $\mathrm{N}$ cloth "should" be $80 \%$ of $\$ 67.55$, or $\$ 54.04$. The beers-based mathematical formula explained each line again, confirming the method in the later 1828 memorandum drawn up by Jackson. Additionally, the 1824 sheets make clear the considerable variation between what was thus posited as the "normal" profit versus the market prices.

If we accept that a quality-based allocation of costs prevailed at BMC throughout much of the $1820 \mathrm{~s}$, what does that tell us about institutionalized cost accounting practices and their use by managers? Let us address the former first, the latter is addressed in the next section. We should recall that the cost calculations were based on aggregate data (mill or corporation-wide costs of cotton, labor and overhead), then combined with information on cloth quality (beers) and data gathered at the end of the production process (yardage, cloth weight). None of these imply a form of control or measurement within the production process itself. More importantly, the beers number was a qualitative element, the introduction of which made the 
calculation more refined, but with a result which could be very different from actual costs. Despite the apparent weakness of the cost formulae, we can offer an institutional explanation for their development and ongoing use. Based on our earlier descriptions of rules, cost the formulae are rules as they explain how things should be done. The origin of these rules was the cost consciousness (a cognitive structure as per Oliveira and Quinn, 2015) of managers at Waltham and Lowell who operated within an Early Modern, merchant framework. We can see this clearly in Appleton's 1824 memorandum (Table 2). The very fact that the cloth with the oldest production history served as the baseline for all other cloths was a throwback to the 18th-century notion of fair price - past habits were a point of reference for the rule represented in the formulae. Jackson and Appleton were both 18th-century merchants and price-takers. Traditional merchant price-setting mechanisms relied on past history, and also on a rule-ofthumb "advance" - gross markup was set at a level which should generate a profit, given past experience (Gervais 2012). Having established the cost formulae as rules, from the memoranda we can also state that these rules were enacted as routines (the way things are done). Based on Table 1 and 2, and following Pentland's (2011) criteria, we can state:

1) the cost calculations were repetitive - they were done in at least 1824 and 1828 , and likely intervening years. They were also done for each cloth.

2) a recognizable and similar pattern of action is shown on each of the memoranda

3 ) the costs calculations were based on accounting records, and likely used for decision-making (see also later), making a sequence of interdependent actions

4) we can be certain that at least Jackson and Appleton were involved, and possibly others.

Thus, we can also regard the cost calculations as a routinized accounting practice. In turn, as we have the interaction of both rules and routines, we can tentatively say that the cost calculations also represent institutionalized practices. And as suggested by Burns and Scapens (2000), these practices were grounded in past institutional practices - i.e. a merchants takenfor-granted way of doing business.

\section{Unit costs and target prices: managerial use of cost information at BMC}

Turning to how the costs were used by managers, Jackson and Appleton operated in a world in which both costs and prices were mostly given, and opportunities arose from price 
fluctuations in segmented markets, often a cyclical affair, with a "fair price" as a baseline. They did not act on production costs per se, but rather tried to fit goods at a certain price into a market segment which would accept them. Moreover, these goods were not really defined "products", rather sets of products, the quality and cost of which fluctuated as much as market prices themselves. In such an environment, the way in which each individual product contributed differentially to the overall profit was less important than the overall quality and range of goods included in each set to which each individual product belonged (Gervais 2012, 2015; Grenier 1996; Jeannin 1996, 2002; McWatters and Lemarchand 2013; Yamey 2000). As revealed by Table 1 and 2, what was measured was not so much the unit cost of an individual cloth, nor even the possible deviation between this unit cost and some ideal target, but the conformity of a range of qualities to the market prices offered for them. All else being equal, which was precisely what quality-based allocation did by smoothing out differences in labor and wastage, the question answered was whether the cost differentials between a given cloth quality and another were properly reflected in the difference in market price? This was in some ways value-based costing, close to later equivalent methods of costing based on an end-of-process valuation serving as a benchmark (Levant and Zimnovitch 2013; Phelizon and Kerdellant, 1992). ${ }^{4}$ To put it another way, actual costs were assessed for the whole of a product set, and absorbed by individual products in proportion to the quality level they contributed to the set. In this way, each quality was debited with the share of the costs it was supposed to absorb given its place in the overall hierarchy of qualities.

Thus, the issue was not "actual" costs, but how a given quality "should" be valued on the market compared to all the other qualities produced, in order to ensure an overall profit. The Waltham cost calculations were a major step forward in this respect, since they provided a formalized, quantified and reasonably objective way to generate, for each cloth quality, a monetary value relative to the other cloth qualities - including new qualities, which could be priced using the beers-based formula. What was built was a price/quality index, measuring the theoretical level at which a particular product would be priced considering not its actual cost, but its place in the overall range of cloth qualities. Using this, managers could then measure market performance, as a comparison between expected price and realized price for each level of quality. This could be done very simply, by comparing the theoretical prices and profits derived from the beers-based price/quality index to actual sales prices recorded on the marketplace. As long as the latter were equal or superior to the value calculated from the price/quality index, managers were reasonably assured of profit, with each cloth quality 
bringing in at least its "allocated" share of profit. This was also a typical merchant approach because the process of tracking and reacting to changes was centered on market prices rather than production costs. Variation in production costs were automatically taken care of at the level of the whole product set, and then absorbed by each product according to its quality index. Market prices, however, had to be monitored as changes in price, not cost, prompted managerial reactions. This is best exemplified by the debate over whether to produce "coarse" or "fine" cloth. The traditional view, inherited from generations of textile merchants, was captured by Appleton in an 1827 letter to an English stockholder of the MMC. According to Appleton:

fine goods now pay much the best profits and the printing business is sure to do well. Everything promises well at Chelmsford - but I am apprehensive they may be deficient in the means of bringing forward new and fashionable patterns so fast as is desirable on which the profit will of course be greatest. ${ }^{5}$

One had to follow market evolution, adapt to consumer taste, and capture high-end segments of the market, supposedly more profitable. While adaptation of product range to market taste was everything, what had to be controlled was not cost per se, but the number of products for which market prices were not high enough compared to what their sales value should be considering quality. "Should" is a key word here - what the 1824 memo contained were not standard costs in the present day sense, but what may be best termed target prices and standard profits. The job of a merchant was to obtain the right price, much more than to impose the right cost. The focus on target prices characteristic of Early Modern merchants is thus a positive explanation which can be offered for the peculiar process whereby costs were computed at the BMC. It is also possible to reinforce this conclusion by pointing out the extent to which actual unit costs were not the focus of managers of BMC, even in areas where their use would have seemed possible. There are at least three ways in which such a lack of focus can be shown: 1) the fact that yearly inventories did not rely on costing, and used market prices instead; 2) the way in which the managers at Waltham used these figures in their strategy; and, 3) the extent to which the beers-based formulae diverged from actual costs. We explore each of these three in turn.

Several authors (Porter 1980; Lubar 1983; Tyson 1992) have argued that the yearly inventories of cloth provided by managers in both Waltham and Lowell reflected actual unit costs. Each cloth had a particular valuation in cents, but there is reason to think that this valuation was a based on current market prices, not cost estimates. Good practice at the time 
required the use of market price for inventories (Chambers and Wolnizer 1991), and there is strong evidence from the inventories themselves that this was so (see Table 3). For each year but one from 1819 to 1822 , average inventory valuation was much closer to average market price than to average cost. Unfortunately, no detailed record of sales survives for the $1820 \mathrm{~s}$, since from 1822 on, B. C. Ward \& Co., Appleton's firm in charge of selling Waltham production, stopped providing the yards sold and listed only their value. As for the one atypical year, 1819, it was the year of the worst economic and financial crisis suffered by the United States in the 19th century. It is probably no coincidence that Jackson valued his inventory quasi at cost for that year only. In other years, Jackson seemed to reduce the inventory value by a few cents compared to market values, probably for prudence reasons and he did this to the inventory value in a perfectly linear way. Thus in 1821 , he valued below market price for his two lowest ranked cloths by 2.5 cents a yard, the next two by 3 cents a yard, the next two by 4 cents a yard, and the two highest ranked cloths were reduced in value by 6 cents.

[insert Table 3 about here]

The valuation of the inventory using market price as a base suggest that unit costs were not uppermost in the minds of BMC managers, or at least the cost calculations they performed were not used for this purpose. It seems that these calculations were not used for strategic planning or product choice either. We can compare the structure of cloth production at the Waltham mills in 1828 to the various cost and profit hierarchies generated in the 1824 and 1828 memoranda for the BMC, as per Table 4. From this comparison, there seems to be no attempt to increase production of either the most profitable cloths, or of those which displayed the highest gain compared to their forecasted performance i.e. cloths which seemed to perform most in excess of their expected target price. Indeed, by 1828 the top three produced cloths, BMC, $\mathrm{N}$ and $\mathrm{S}$, were also among the least profitable ones, regardless of the yardstick applied.

[insert Table 4 about here]

Thus, the perception of differing rates of profit per cloth seemed to have had virtually no effect on strategy. This lack of effort to move to more profitable cloths may be baffling, but there is a potential explanation. While the cost calculations in the memoranda did provide a 
consistent and logical basis to check the hierarchy of market price, they may have had little to do with actual costs. As we have noted, assuming a linear relationship between beer numbers and labor, or between cloth weight and cotton consumption, could be misleading. As it happens, the degree of error generated by the formulae as per Figures 1 and 2 can be determined with a good deal of accuracy. Several of the corporations in the new city of Lowell set up specialized mill units, where one factory building produced one type of cloth. Thus by 1828 , the MMC operated five mill units, four of which were specialized (see Table $5)$.

[insert Table 5 about here]

Because of the careful accounting process, inputs and outputs were recorded for each mill unit. Moreover, at MMC both the incoming cotton and the outgoing cloth were weighed, so that a wastage figure could be given (assuming stocks carried over were correctly factored in). With this data, it is possible to calculate actual costs i.e. cotton actually consumed and labor actually used (overhead still needs to be allocated), for each specialized mill unit. By treating the four specialized mill units as one multi-product unit producing four cloth types, it is also possible to compare these actual costs to the cost figures generated by allocating labor and overhead according to the beers-based formula developed at Waltham, and allocating cotton consumption on the basis of final cloth weight (see Table 6).

[insert Table 6 about here]

The error generated by the beers-based formula turns out to have been significant whenever a given cloth was characterized by large deviations from the norm for wastage or labor costs. For instance, the production of cloth $\mathrm{E}$, which was a very fine cloth with the second highest beer count, generated $28 \%$ waste, and high labor costs of $\$ 6.67$ per yard (see Table 6). If the Waltham formulae was applied, cotton waste was equalized between cloth types, since the basis for the calculation was finished cloth, and the quantity of extra labor needed was underestimated due to an assumed linear relationship between beers and labor. In other words, the Waltham formulae hid precisely what unit cost calculations are supposed to focus on today, the presence of less profitable, problematic products. This may well explain why 
Jackson and Appleton made limited use of their own costing efforts - they themselves were conscious of the limitations. Certainly in their papers, both men called their cost assessments "calculations", the same word they used for the ex-ante profit analyses for new ventures or new grades of cloth described by Tyson $(1992,1998)$. The fact that their unit cost memoranda were not included in reports to directors for example, and were physically mixed with such prospective estimates, is another sign that the value of the two exercises was deemed similar. The quality-based profit forecasts they contained were certainly used to evaluate market prices and overall profit prospects, particularly when new ventures were being launched which explains why these worksheets appeared at the time when first the Merrimack (1824), then the Hamilton and Appleton companies (1828) started production. Their authors may have realized that the results of their calculations were significantly different from actual costs, and thus did not use them as a basis for changes in the product mix, as suggested earlier. Of course, another explanation for the non-use of the cost calculations may be what we noted earlier - the cost calculation practices to some extent encompass an engrained merchant mindset and this mindset is institutionalized. Barring major forces for change, typically from an external source (Burns and Scapens 2000), even if the cost calculations "could" be improved or used by management in a better way, their institutional nature will foster stability

\section{Moving toward use of actual cost - the MMC memoranda}

The advent of specialized mill units represented a turning point in the cost accounting practices of Jackson and Appleton, at least for the new production center set up in Lowell. The change to costing was not sudden. Beers-based formulae were still used in 1828 in Waltham, as we have seen, but they were not used at MMC where only one mill unit put out two kinds of cloth. At first the cloth produced, and the resulting quality scale, were the same in both places so that once the quality scale had been checked at Waltham there was no need to check again at the sister complex in Lowell. Appleton still drew up several costing sheets from 1825 onwards when balancing the books in April or October of each year (Tyson 1992: 11). He maintained the approach he had practiced at Waltham at first, allocating cotton costs based on cloth weight rather than actual consumption; but, on labor and overhead allocation, he did not use the beers-based calculation, using instead cruder, simpler methods.

For instance, in his earliest surviving effort from 1825 (see Table 7), Appleton used the same 
approach as at Waltham for cotton costs, allocating them on the basis of cloth weight, without taking into account differential waste. He listed 68,495 lbs of cloth $\mathrm{C}$ produced, for instance, or $42.68 \%$ of the $160,481 \mathrm{lbs}$ overall. On the other hand, cloth $\mathrm{C}$ was presented as costing 4.70 cent per yard in cotton, which meant that the 359,143 yards of cloth $\mathrm{C}$ produced had a cotton cost of $\$ 16,879.72$. This was, not coincidentally, $42.67 \%$ of the $\$ 39,559.23$ (see Table7) worth of cotton used in the entire company at the time.

[insert Table 7 about here]

To allocate labor and overhead, Appleton did not apply the beers-based formula. Overhead was split 50/50 between the two mill units, Mill 1 and Mill 2, with $\$ 4185.38$ each (see Table 7), even though Mill 1 produced almost 15\% more cloth than Mill 2 and also produced finer cloth. For Mill 1, where labor and overhead were allocated between cloth types A and B, Appleton simply added the labor and overhead expenses, and split them 50/50 between the two types of cloth. With 238,877 yards at 15 cents a yard, cloth A (a coarse cloth), was charged with half of the $\$ 19,315.14$ spent on labor and overhead or $\$ 0.0405$ per yard. Mill 1 produced 171,783 yards of Cloth B, a finer cloth and was nonetheless charged with half the labor and overhead spend, thus costing \$0.0587 cents a yard (see Table 7). Again, actual costs were not yet a focus of Appleton, who distributed costs across cloth types to compare profits and sales prices over the whole set of products, charging costs more or less according to quality. The quantity of a type of cloth produced over a year, which he used for his allocation, was an inferior proxy to fineness, but it was still a proxy; there was an imperfect but still linear relationship between yearly production and beer count, with the highest beer counts produced at half the rate of the lowest ones (cf. Table 1).

On a second sheet, dated October 1827, Appleton used what may have been the 1826 averages to calculate 1827 costs estimates. ${ }^{6}$ Writing "when Mill 1 av[erage]d 8,47 A cost 7.77 W 9.57", he set the cost per yard of cloth $\mathrm{A}$ at 7.02c and the equivalent cost for W (which replaced B) at 8.64c. These were derived from the average cost per yard for Mill No. 1, which was $7.65 \mathrm{c}$, and then applying the proportion as per the preceding year $(7.77 / 8.47=7.02 / 7.65)$. However, cotton costs for Mill No 2, 3 and 4 (all single-product mill units) was accounted for separately for each mill. Thus, for the first time in 1827 , costs were calculated for each type of cloth at these specialized mill units, rather than allocated from aggregate data. Appleton 
also specified that "why the real waste [in cotton] does not appear is because the stock in Mills is not same as in April last." This could be taken as an indication that Appleton was starting to manipulate mills cost centers in a more elaborate fashion, distinguishing between "apparent waste" (cotton inputs to a mill minus weight of cloth output) and "real waste" (the same figure corrected by taking into account beginning and ending stocks of cotton within a mill unit). These possibilities were not necessarily clearly perceived by him, though, as is demonstrated by another sheet from the same month of October 1827, presenting cotton and labor costs per grade of cloth for the six months ending October $15 .^{7}$ In this sheet, cotton costs were calculated by dividing yardage by cloth weight produced in each mill unit, and multiplying the resulting figure by a standard 16.35 cents - presumably the average cost per pound of cotton. Labor was allocated within a table, titled "Proportion of Labor to Beers" where again, the values were derived from aggregate data and weighted by beers numbers. What is surprising here is not that Appleton was applying his usual quality-based approach, but that he was applying it to three types of cloth for which he had provided exact costs in another calculation made the same month on another piece of paper.

The cost calculations remained similarly inconsistent - especially for cotton - in the last series of memoranda from the 1820s. These were drawn up in 1828 and 1829 by Jackson for AMC, MMC and HMC. ${ }^{8}$ Cotton weight per grade of cloth appear alongside yardage and original cotton poundage only in the two earliest memoranda, from October 1828 (AMC) and May 1829 (MMC). Overall cotton consumption was greater than total cloth weight, and implied wastage figures varied from mill to mill, which indicates that original cotton weight and final cloth weight were measured independently, a major departure from the assimilation of cloth weight to cotton used which was applied in Waltham. However, both the second AMC memorandum and the second MMC memorandum gave only cloth weight, not cotton consumption, so we cannot ascertain which weighing process was used. As for the HMC factory, no cloth-specific weight was given and only one cotton figure was apparently recorded for the two multi-product mill units; thus, we cannot determine if the figure given was the total poundage of cloth produced or the total amount of cotton brought into the mills. Whenever a mill unit manufactured several grades of cloth, as was the case at the MMC Mill 1 and in both mill units at $\mathrm{AMC}$, there was one cotton input figure, and consequently one overall wastage figure for the whole mill unit. This tends to confirm that there was no system for recording how much cotton was expended on a given grade within a mill. Also, as there is no way to check how labor figures were arrived at in the Jackson memoranda, there is no 
reason to suppose they were built through any such internal tracking process either. ${ }^{9}$

Tyson's data from the 1830s (see Tyson 1992, 1998) should be considered within this broader context. By 1828, it would seem a move toward mill-based accounting was starting, which is illustrated in the memorandum from October 1828 noted above in Table 5. As far as we can ascertain, this is the first time since the $1810 \mathrm{~s}$ and the beginning of BMC at Waltham (when one mill and one cloth type existed) that actual inputs and outputs were recorded rather than allocated. The issue of multi-product mill units remained, however, with the sheet for 1830 at MMC showing allocation of overall costs by formula between the two grades of cloth produced in Mill $1^{10}$. From the end of the 1820 s on, the possibility of measuring accurately inputs for cotton and labor per type of cloth became clearly apparent, at least in the specialized single product mills. With just one cloth type, there was no need to allocate labor and cotton between several types, and the careful accounting of inputs and outputs already characteristic of Waltham's detailed financial reporting gave accurate unit cost figures. Only overhead remained problematic, since a given company could have several mill units, and allocation was still required. Thus, the accelerating move toward specialized mill units at the end of the 1820s in Lowell is important in the explanation of how more accurate unit costs came about. Tyson $(1992,11)$ does note this, but it may deserve more prominence. As some companies in Lowell were built around specialized mill units, Jackson had achieved reasonably accurate actual unit costs for various types of cloth in 1828, and as early as 1824 for the single-product Mill 2 of MMC (see Table 7).

In terms of institutionalized cost accounting practices as already described, the MMC memoranda show some evidence of variations creeping in - the cost calculations and allocations are not exactly the same as those described earlier for the BMC. As noted by Burns and Scapens (2000) change can come about through external shocks to an organization (more revolutionary change) and/or from internal sources as rules and routines in particular vary as they are acted out. The next section considers such potential change sources

\section{Change from quality pricing to cost control?}

It is likely that single-product mill units in and of themselves would not necessarily have been enough to prompt Appleton to give up on his beer-based approach to costs, which he maintained throughout the 1820 s as recounted above. The fact that some types of cloth were 
too costly to produce did eventually lead to managerial action in 1827 , when the directors of HMC noted that "the fine goods which we made are found to be worth very little more than those of a coarser description and costing much more" (Tyson 1998, 220). They thus decided to switch part of their production to coarser goods. While we do not know what kind of calculation (arbitrary beers-based allocation or actual measurements on the shop floor) served as a basis for this comparative statement, the fact that it was made, and acted upon, marks a significant step in the evolution toward calculations of costs per product line and a corresponding effect on strategy. Still, unit cost data, if they were used at all, were used merely to reallocate resources rather than to act on the production function itself. The obvious inefficiencies associated with specific (finer) cloth types did not lead to an effort to identify the source of the problem, reduce cost and/or increase productivity for these particular products. Nor did it prompt Jackson to give up on the beers-based formula in his calculations the following year, or to insist that any mill unit created thereafter should be single-product. At the Appleton Company (formed in 1828), both mill units were multi-product, as was Mill 1 of the MMC and both mill units operated by HMC. By 1830, of eleven mill units in these three companies, seven still produced at least two cloth types. And as late as 1834 , in the Lawrence Manufacturing Company, launched in Lowell three years earlier, memoranda published by David Porter (Porter 1980, 4-5) show that three of the four mill units there were multi-product. In all three, the percentages of cotton, labor and general expenses costs allocated to each cloth were identical to the percentage of the weight of said cloth to total cloth weight. ${ }^{11}$ In other words, Lawrence Company managers were using Appleton's weightbased approach, which we have noted earlier at the MMC (see Table 7).

Generally, the calculation of unit costs remained a quality-focused rather than productionfocused exercise in Waltham, and in Lowell as well (although less uniformly) until at least the end of the 1820s. A first consequence of this is that the tracking of such costs was not a given at first, and hence not a natural consequence of technical innovation. The groundbreaking introduction of the power-loom to the United States was in 1813, and fifteen years later Jackson and Appleton still relied on aggregate and average data to calculate unit costs. It is beyond the scope of this paper to try and pinpoint the moment when differences in unit costs and related comparative productivity issues took center stage. More likely, the usefulness of tracking precisely and continuously the cost of each cloth to identify inefficiencies or potential productivity gains within the production process emerged from the end of the $1820 \mathrm{~s}$ 
on. Tyson $(1992,1998)$ has identified several instances at the beginning of the 1830 s where managers tried to achieve predefined productivity gains, notably with the appearance in 1830 of production targets associated with cash incentives, and most famously, with the 1836 letter asking the Appleton company to "wake up [...] and try to beat [the Jackson Manufacturing Company] the next six months to come" (Tyson 1992, 13; Tyson 1998, 218). Another sign of an increased willingness to tinker with the production process in more detail was an emphasis on wage-cutting, or at least wage control. As far as we could determine, this willingness appears for the first time in Appleton's correspondence in May 1827, through a letter from Kirk Boott, the agent at Merrimack, listing the (implicitly reduced) rates he is trying to force upon the printers of the factory, ${ }^{12}$ and it may explain the drafting of a list of wage rates from 1829 , also unearthed by Tyson $(1992,14)$. Printing costs were also more closely monitored as also shown by Tyson (1992, 12-13), and while we do not have enough data to know how such costs were calculated, it may be that the rather complex values recorded were the results of observation of the labor process rather than overall allocation. ${ }^{13}$ The differences between Waltham's beers-based calculations and the MMCs methods in Lowell may also have played a role, since Jackson and Appleton were bound to notice the discrepancies between the two.

The change process away from the beers-based costs emerged slowly, and may also have been influenced by broader market an economic evolution. The shift to more widespread single-product mill units, and the first tentative efforts toward deriving unit costs from observation of the production process both occurred during a time of change in the fortunes of the large cotton textile factories in the United States. As Table 8 shows, the Waltham Company experienced falling profit margins from 1824, after almost ten years of good returns. While routinely at or above $20 \%$ until 1824 , return on investment as calculated from the books decreased to a less impressive $10-12 \%$ by the end of the $1820 \mathrm{~s}$ - and this trend continued into the 1830s (see McGouldrick 1968). This decline in returns may have been a result of a more competitive business environment, as more cotton mills relied on greater automation. Thus, unit cost calculations may have acquired more importance due to the declining results - a point which holds true also, it seems, for the Slater mills (Tyson 1992, 4).

[insert Table 8 about here]

Additionally, it is also possible that the returns per Table 8 were not in fact declining, but the earlier returns were higher than normal. An economic boom preceded the 1819 crisis in the 
United States economy (see Rothbard 1962). This created excess demand and profits in the economy in general, which declined after 1819. Thus, these tougher economic conditions, combined with greater competition as noted above added to the impetus for change. To put this in Burns and Scapens (2000) terms, external shocks caused the existing institutions to unravel. This process occurred over perhaps a decade or two, arguably starting with the introduction of the power loom in 1813, a potential external shock in the form of new technology. Although not the subject of this paper, it is quite likely that merchants like Jackson and Appleton realized (at least in their minds) that the way business was done was changing. This did not necessarily cause change per se at the time, but over time, their existing ways of doing things (from a merchant background) were challenged at a cognitive level. By 1828, the beers-based formula, which was deeply engrained in the merchant mindset, showed signs of change. The change was brought about over time by the realization that external business conditions (another external shock) required a different way of calculating costs.

\section{Final thoughts}

The Waltham records described here have allowed us to explore the detailed cost figures produced, and also how they were produced and offer some suggestions on their potential use. They show that apparently detailed cost calculations made at the beginning of the industrial age could have complex meanings, but not necessarily the meaning we would ascribe to them today. Measuring unit costs was one thing, but measuring these costs within the production process and using them specifically for product choice and product development, was another. Jackson and Appleton produced unit cost figures to a thousandth of a cent, but from average data. These costs were significantly different from unit product costs (i.e. when costs were traced to each cloth type), a fact of which both men may have been fully conscious. Still, they did not attempt to parse the production process itself to identify specific sources of cost inefficiencies. While they seem to have used the figures from time to time, they did not turn them into a basis for sustained management of various product lines, at least not before the end of the 1820s. However, this does not mean that the cost calculations described here were useless. As we have noted, Appleton and Jackson had both trained as merchants, and came to manufacturing with a merchant mindset. This mindset wished to ensure that the costs incurred in producing the whole basket of products were in line both with the hierarchy of cloth qualities and with market prices. In other words, these calculations embodied existing 
institutionalized practices - a traditional merchant approach. However, even these deeply engrained and taken-for-granted practices eventually showed signs of change towards our own present-day way of doing calculating unit costs. This gradual change was a result of external pressures (indeed shocks) as described by Burns and Scapens (2000).

We should also note some other features of this study. As noted by Quinn (2014), using archival records has limits when using an institutional framework to offer explanations for findings. A key limitation is the inability to observe action, an essential component of routines. Here likewise, we cannot observe actions. However, our reverse engineering method has allowed us to gain deeper insights as to why these costs calculations were done in the way they were. This method could be easily applied in other accounting history studies where ample archival records exist. Of course, there is also a limitation in this method in that we cannot be absolutely sure that our reverse engineering and subsequent understanding of the calculations is absolutely correct. However, it does provide an additional triangulation aspect to our interpretations and we would encourage further similar studies. 


\section{Bibliography}

Appleton, N. 1848. Correspondence between Nathan Appleton and John A. Lowell in relation to the Early History of the City of Lowell. Boston: Eastburn's Press.

Appleton, N. 1858. Introduction of the Power Loom and Origin of Lowell. Lowell, MA.: B. H. Penhallow.

Berg, M. 1994. The age of manufactures, 1700-1820. London: Routledge.

Chambers, R. J. and P. W. Wolnizer. 1991. "A true and fair view of position and results: the historical background". Accounting, Business and Financial History 1(2): 197-213.

Dalzell, R. F. 1987. Enterprising elite: the Boston associates and the world they made. Cambridge, MA: Harvard University Press.

Dublin, T. 1979. Women at Work: The Transformation of Work and Community in Lowell, Massachusetts, 1826-1860. New York: Columbia University Press.

Edwards, J. R., G. Dean and F. Clark. 2009. "Merchants' accounts, performance assessment and decision making in mercantilist Britain". Accounting, Organizations and Society 34(5): 551-570.

Fleischman, R. K. and L. D. Parker. 1997. What is past is prologue: cost accounting in the British industrial revolution, 1760-1850. New York: Garland.

Gervais, P. 2012. "Mercantile Credit and Trading Rings in the Eighteenth Century". Annales Histoire, Sciences Sociales 67(4): 693-730.

Gervais, P. 2014. Why Profit and Loss Didn't Matter: The Historicized Rationality of Early Modern Commerce. In Merchants and profit in the Age of Commerce, 1680-1830. P. Gervais, Y. Lemarchand and D. Margairaz ed. London: Pickering \& Chatto, 33-52.

Gervais, P. 2015. Facing and surviving war: merchant strategies, market management and transnational merchant rings. In A. Bonoldi et al. (eds.). Merchants in Times of Crises (16th to mid-19th Century). Stuttgart: Franz Steiner Verlag, 79-94.

Gibb, G. S. 1950. The Saco-Lowell shops: textile machinery building in New England, 18131849. Cambridge, MA: Harvard University Press.

Gregory, F. W. 1975. Nathan Appleton: merchant and entrepreneur 1779-1861. Charlottesville: University Press of Virginia.

Grenier, Jean-Yves. 1996. L'économie d'Ancien Régime. Un monde de l'échange et de l'incertitude. Paris: Albin Michel.

Hancock, David. 2009. Oceans of Wine: Madeira and the Emergence of American Trade and Taste. New Haven: Yale University Press.

Hiebl M.R.W., M. Quinn, and C. Martínez-Franco. 2015. "An analysis of the role of a Chief Accountant at Guinness c. 1920-1940." Accounting History Review 25 (2): 145-165.

Hoskin, K. W. and R. H. Macve. 1996. "The Lawrence Manufacturing Co.: A note on early cost accounting in US textile mills". Accounting, Business and Financial History 6(3): 337-61.

Jeannin, P. 1996. Marchands du Nord: espaces et trafics à l'époque moderne, Paris: Presses de l'ENS.

Jeannin, P. 2002. Marchands d'Europe: pratiques et savoirs à l'époque moderne, Paris: Presses de l'ENS.

Jeremy, D. J. 1981. Transatlantic Industrial Revolution: the diffusion of textile technologies between Britain and America, 1790-1830s. Cambridge, MA: MIT Press.

Johnson, R. I. 2000. "In search of E. I. Du Pont de Nemours and Company: The perils of archival research". Accounting, Business and Financial History 10(2): 129-68.

Lefebvre, P. 2003. L'invention de la grande entreprise. Paris: Presses Universitaires de France.

Levant, Y. and H. Zimnovitch. 2013. "Contemporary Evolutions in Costing Methods: 
Understanding These Trends through the Use of Equivalence Methods in France". Accounting History 18(1): 51-75.

Lubar, S. D. 1983. "Corporate and urban contexts of textile technology in Nineteenth-Century Lowell, Massachusetts; a study of the social nature of technological knowledge". Ph. D. Diss. University of Chicago.

Mailloux, K. F. 1957. "The Boston Manufacturing Company of Waltham, Massachusetts, 1813-1848: the first modern factory in America". Ph. D. Diss. Boston University.

Margairaz, D. 2014. "Product Quality and Merchant Transactions: Product Lines and Hierarchies in the Accounts and Letters of the Gradis Merchant House". In Merchants and profit in the Age of Commerce, 1680-1830. P. Gervais, Y. Lemarchand and D. Margairaz ed. London: Pickering \& Chatto, 115-131.

Marglin, S. 1974. "What do bosses do? The origins and function of hierarchy in capitalist production". Review of Radical Political Economics 6(2): 33-60.

McWatters, C.S., and Y. Lemarchand. 2013. "Merchant networks and accounting discourse: the role of accounting transactions in network relations". Accounting History Review 23(1): 49-83.

McGouldrick, P. F. 1968. New England Textiles in the Nineteenth Century: Profits and Investments. Cambridge, MA.: Harvard University Press.

Meyer, D. R. 2003. The Roots of American Industrialization. Baltimore: The Johns Hopkins University Press.

Mokyr, J. 2005. "The intellectual origins of economic growth". Journal of Economic History 65(2): 285-351.

Oldroyd, D. 1999. "Through a glass clearly: management practice on the Bowes family estates c. 1700-70 as revealed by the accounts". Accounting, Business and Financial History 9(2): 175-201

Oliveira, J. and Quinn, M. 2015. "Interactions of rules and routines: re-thinking rules". Journal of Accounting \& Organizational Change, 11(4): 503-526.

Phelizon, J. F. and Kerdellant, C. 1992. Comment les Japonais calculent les prix de revient. Harvard-L'Expansion 64: 72-77.

Porter, D. M. 1980. "The Waltham system and early American textile cost accounting". Accounting Historians Journal 7(1): 1-15.

Previts, G. J. and Merino, B. D. 1998. A History of Accountancy in the United States: The Cultural Significance of Accountancy. Columbus, Oh.: Ohio State University Press.

Quinn, M. 2011. "Routines in management accounting research: further exploration". Journal of Accounting \& Organizational Change 7(4), 337-357.

Quinn, M. 2014. "Stability and change in management accounting over time-A century or so of evidence from Guinness." Management Accounting Research 25 (1): 76-92.

Quinn, M., and W. Jackson. 2014. "Accounting for war risk costs: management accounting change at Guinness during World War 1." Accounting History Review 24 (2-3): 191-209.

Rothbard, M. N. 1962. The Panic of 1819. Reactions and Policies, Austria: Ludwig von Mises Institute.

Rothenberg, W. B. 2002. The invention of American capitalism: the economy of New England in the Federal period. In Engines of Enterprise: An Economic History of New England, ed. P. Temin: 69-108. Cambridge, MA.: Harvard University Press.

Scorgie, M. E. 1999. "Progenitors of modern management accounting concepts and mensurations in pre-industrial England". Accounting, Business and Financial History 7(1): 31-59.

Spraakman, G. 2006. "The impact of institutions on management accounting changes at the Hudson's Bay Company", Journal of Accounting and Organizational Change 2(2): 101122. 
Stanziani, A., ed. 2003. La qualité des produits en France, $X V I I I^{e}-X X^{e}$ siècles. Paris: Belin.

Tyson, T. N. 1992. "The nature and environment of cost management among early Nineteenth-Century U.S. textile manufacturers". Accounting Historians Journal 19(2): 124.

Tyson, T. N. 1998. "Mercantilism, management accounting or managerialism? Cost accounting in early Nineteenth-Century textile mills". Accounting, Business and Financial History 8(2): 211-29.

Ware, C. F. 1931. The early New England cotton manufacture: a study in industrial beginnings. Boston: Houghton Mifflin Company.

Yamey, B. S. 2000. “The 'Particular Gain or Loss Upon Each Article We Deal In' : an aspect of mercantile accounting, 1300-1800”. Accounting, Business and Financial History 10(1): $1-12$.

1. For Jackson's version, see "Memorandum book on textile manufacturing companies," Folder 16, vol. 42, Patrick Tracy Jackson Papers, Ms. N-408 [Tall], Massachusetts Historical Society, Boston, Mass. Appleton's version, cleaner in presentation than Jackson's, almost certainly derives from the latter, cf. "Mem(o) of the cost of Cloth made in 53 weeks from August 251827 to August 30 1828," Box 4 "General Correspondence, etc. 1826-1831," Folder 9 "1828 May-Dec," Appleton Family Papers, (Ms. N-1778, Massachusetts Historical Society, Boston, Mass).

2. Accounts Current (1822-1831), vol. 35, Boston Manufacturing Company Fund (Mss 442, Baker Library Historical Collections, Harvard Business School, Boston, Mass.), February and August 1828, 122, 150.

3. As costs were calculated before the yearly directors' meeting in October, these tables must have been made in September 1824. At any later date, Appleton would have used the data from 1823-1824. Both memoranda were misfiled with correspondence from 1822 and 1823.

4. The formal similarity between the Waltham/Lowell quality-based costing methods and later attempts at equivalence methods was pointed out to me by Yves Levant, who also pointed us to the paper by Phelizon and Kerdellant, and whom we thank here.

5. [N. Appleton] to "Th(o) Wiggins", December 1824, Box 3, Folder 14, Appleton Family Papers.

6. "Mem(o) of Cloth made and its cost at Lowell Oct. 15. 1827," Box 4, Folder 7, Appleton Family Papers.

7. "Mem. of M. Cloth made 6 mo. Oct. 1827," Box 4, Folder 7, Appleton Family Papers.

8. A series of tables found in the same memorandum book used above, Folder 16, vol. 42, Patrick Tracy Jackson Papers, p. 8-9 and 13-16.

9. "Cost of Cloth made by the Merrimack Man Co in 6 mos ending Oct. 1828," "Memorandum book," Folder 16, vol. 42, Patrick Tracy Jackson Papers, p. 13; "Appleton Co. Mem(o) of Cloth made to May 30. 1829", "Memorandum book" Ibid. p. 8; "Appleton Co. Mem(o) of Cloth made in 6 mos to Nov(r) 28 $8^{\text {th }} 1829$," Ibid. p. 9; "Cloth made 6 mos. to 11 April 1829" (also in the Merrimack, since the same five mills and cloths are listed), Ibid. p. 15. The table p. 13 is reused in part p. 14; "Hamilton Company - Cloth made in [blank] weeks ending Dec(r) 29th 1829," Ibid., p. 16.

10. "Examination of Profit in each mill 6 mos. ending Oct(o) 11 1828" and "M.M.C Oct 1828," Box 4, Folder 9; and "Cost of each Cloth and gain in each mill in October 1830," Box 4, Folder 12, Appleton Family Papers.

11. The memoranda do not contain the figures for each cloth, but provide cost per yard, total yardage and poundage for each cloth "X". By multiplying this cost per yard by total yardage, one gets the total cost of cloth "X". Calculating the percentage of the weight of cloth " $\mathrm{X}$ " produced with respect to total weight, and applying that percentage to the total value of cotton, gives the value of cotton used for cloth " $\mathrm{X}$ ". By subtracting this cotton value from the total cost of cloth "X," we get the cost of labor plus general expenses for cloth "X", which we can compare to factory-wide costs.

12. Kirk Boott to Nathan Appleton, May 6, 1827, Box 4, Folder 5, Appleton Family Papers.

13. For instance, "Cost of Finished Prints Oct 14 1826", Box 4, Folder 4, Appleton Family Papers. 